\title{
PENGENALAN POLA HIV DAN AIDS MENGGUNAKAN ALGORITMA KOHONEN PADA JARINGAN SYARAF TIRUAN BACKPROPAGATION
}

\author{
Heru Satria Tambunan \\ AMIK Tunas Bangsa \\ Jalan Sudirman Blok A No. 1-3, Kota Pematang Siantar, Sumatera Utara 21127 \\ heru@gmail.com
}

\begin{abstract}
Abstrak- Perkembangan tekhnologi saat ini sangat berkembang pesat, sehingga sangat memudahkan untuk mengatasi berbagai masalah. Di dalam penelitian ini penulis menggunakan algoritma Kohonen pada Jaringan Syaraf Tiruan Backpropagation dalam pengenalan pola penyakit HIV dan AIDS dalam mengenali pola penyakit HIV dan AIDS. Algoritma Backpropagation merupakan salah satu algoritma pembelajaran yang membutuhkan pengawasan dalam proses pembelajarannya. Pada algoritma backpropagation terdapat pasangan data input dan output serta hidden layer untuk melakukan pemrosesan data Jaringan Syaraf Tiruan hingga diperoleh bobot penimbang (weight) yang diinginkan. Dalam penelitian ini, dalam pengenalan pola penyakit HIV dan AIDS. Penulis menggunakan 15 variabel datauntuk dilatih menggunakan algoritma backpropagation dimana pembobotannya secara random dan data yang kedua dilatih menggunakan algoritma backpropagation. Didalam penelitian ini mengunakan aplikasi matlab untuk melakukan pemrosesan.
\end{abstract}

Keywords - Jaringan Syaraf Tiruan, Backpropagation, Kohonen (SOM), Matlab.

\section{PENDAHULUAN}

A. Definisi Jaringan Syaraf Tiruan Backpropagation Dalam jaringan Syaraf Tiruan (JST) merupakan suatu sistem pemrosesan informasi yang mempunyai karakteristik menyerupai jaringan syaraf biologi(JSB). JST tercipta sebagai suatu generalisasi model matematis dari pemahaman manusia (humancognition) yang didasarkan atas asumsi sebagai berikut pemrosesan informasi terjadi pada elemen sederhana yang disebut neuron, sinyal mengalir diantara sel syaraf/neuron melalui suatu sambungan penghubung, setiap sambungan penghubung memiliki bobot yang bersesuaian. Bobot ini akan digunakan untuk menggandakan / mengalikan sinyal yang dikirim melaluinya, setiap sel syaraf akan menerapkan fungsi aktivasi terhadap sinyal hasil penjumlahan berbobot yang masuk kepadanya untuk menentukan sinyal keluarannya.(Wuryandari, et al, 2012)

Backpropagation merupakan salahsatu algoritma yang sering digunakan dalam menyelesaikan masalahmasalah yang rumit. Hal ini dimungkinkan karena jaringan dengan algoritma ini dilatih dengan menggunakan metode belajar terbimbing. (Matonda, 2013)

Fungsi aktifasi yang dipakai untuk menentukan keluaran suatu neuron. Pada backpropagation fungsi aktivasi yang dipakai harus memenuhi syarat yaitu : kontinu dan terdiferensial dengan muhah (nurhafifah 2011)

Saat ini berkembangan penyakit-penyakit yang dapat ditularkan seperti HIV dan AIDS yang dimana penyakit ini adalah penyakit yang sangat mudah tertular dan penyakit ini biasanya ditulari dengan cara penggunaan narkoba, penggunaan suntik yang tidak steril dan banyak lagi yang menyebabkan penyakit ini tertular. Berdasarkan penelitian ini penulis melakukan penelitian menggunakan Algoritma Kohonen pada Jaringan Syaraf Tiruan Backpropagation untuk mengenali pola penyakit HIV dan AIDS.

\section{B. Definisi Algoritma Kohonen}

Algoritma Kohonen merupakan algoritma jaringan cerdas yang menggunakan sistem pembelajaran secara kompetitif yang bersifat unsurpervised. Dimana sistem pembelajarannya secara pengelompokan atau klasifikasi (cluster)

Jaringan Syaraf Tiruan Self Organizing Maps (SOM) atau disebut juga dengan jaringan Kohonen telah banyak dimanfaatkan untuk pengenalan pola baik berupa pola penyakit, citra, suara, dan lain-lain. Jaringan SOM sering pula digunakan untuk ekstraksi ciri (feature) pada proses awal pengenalan pola. Ia mampu mereduksi dimensi input pola ke jumlah yang lebih sedikit sehingga pemrosesan komputer menjadi lebih hemat.

Pada prinsipnya algoritma Kohonen akan memasukan beberapa node yang dimana node tersebut akan dihitung melalui bobot yang dimasukan setelah node dihitung akan melakukan pengurangan nodenode sehingga yang pada akhirnya hanya satu node yang dipilih untuk menentukan hasil yang maksimal.

Algoritma Backpropagation merupakan algoritma pelatihan terbimbing yang mempunyai banyak lapisan. BPNNmenggunakan error outputuntuk mengubah nilai bobot-bobotnya dalam arah mundur (backward). Untuk mendapatkan error ini, tahap perambatan maju 
(forward propagation) harus dikerjakan terlebih dahulu (Nurmila A, et al)

\section{TINJAUAN PUSTAKA}

\section{A. Jaringan Syaraf Tiruan}

Komunikasi data adalah pertukaran data antara dua perangkat atau lebih melalui media transmisi misalnya seperti kabel. Untuk bisa terjadinya komunikasi data, perangkat harus saling berkomunikasi atau terhubung menjadi sebuah bagian dari sistem komunikasi, yang terdiri atas kombinasi dari peralatan fisik atau keras (hardware) dan perangkat aplikasi atau program (software)[1].

Jaringan Syaraf Tiruan (JST) merupakan suatu sistem pemrosesan informasi yang mempunyai karakteristik menyerupai jaringan syaraf biologi (JSB). JST tercipta sebagai suatu generalisasi model matematis dari pemahaman manusia (human cognition) yang didasarkan atas asumsi sebagai berikut : Pemrosesan informasi terjadi pada elemen sederhana yang disebut neuron, sinyal mengalir diantara sel saraf/neuron melalui suatu sambungan penghubung, setiap sambungan penghubung memiliki bobot yang bersesuaian. Bobot ini akan digunakan untuk menggandakan / mengalikan sinyal yang dikirim, setiap sel syaraf akan menerapkan fungsi aktivasi terhadap sinyal hasil penjumlahan berbobot yang masuk kepadanya untuk menentukan sinyal keluarannya. (Wuryandari, et al, 2012)

Pada dasarnya karakteristik JST ditentukan oleh :

1. Pola hubungan antar neuron (disebut arsitektur jaringan)

2. Metode penentuan bobot-bobot sambungan (disebut dengan pelatihan atau proses belajar jaringan)

3. Fungsi aktivasi

\section{B. Arsitektur JST}

Pada arsitektur Jaringan Syaraf Tiruan (JST), sebuah neuron-neuron akan dikumpulkan dalam lapisan-lapisan atau yang biasa disebut layer. Pada lapisan JST dari lapisan masukan hingga keluaran akan melalui sebuah lapisan tersembunyi yang biasanya di sebut hidden layer.

Menurut (Wuryandari, et al, 2012) Faktor terpenting dalam menentukan kelakuan suatu neuron adalah fungsi aktivasi dan polabobotnya. Umumnya neuronneuron yang terletak pada lapisan yang sama akan memiliki keadaan yang sama sehingga pada setiap lapisan yang sama neuron-neuron memiliki fungsi aktivasi yang sama. Bila neuron-neuron pada suatu lapisan (misal lapisan tersembunyi) akan dihubungkan dengan neuron neuron pada lapisan lain (misal lapisan keluaran) maka setiap neuron pada lapisan tersebut (lapisan tersembunyi) juga harus dihubungkan dengan setiap neuron pada lapisan lainnya (lapisan keluaran). Terdapat 3 macam arsitektur JST, yaitu:

1. Jaringan dengan lapisan tunggal (single layernet) Jaringan ini hanya memiliki 1 lapisan dengan bobotbobot terhubung. Jaringan ini hanya menerima masukan kemudian secara langsung akan mengolahnya menjadi keluaran tanpa harus melalui lapisan tersembunyi. Pada gambar berikut neuron neuron pada kedua lapisan saling berhubungan. Seberapa besar hubungan antara 2 neuron ditentukan oleh bobot yang bersesuaian. Semua unit masukan akan dihubungkan dengan setiap unit keluaran seperti terlihat pada Gambar 1 dibawah ini.

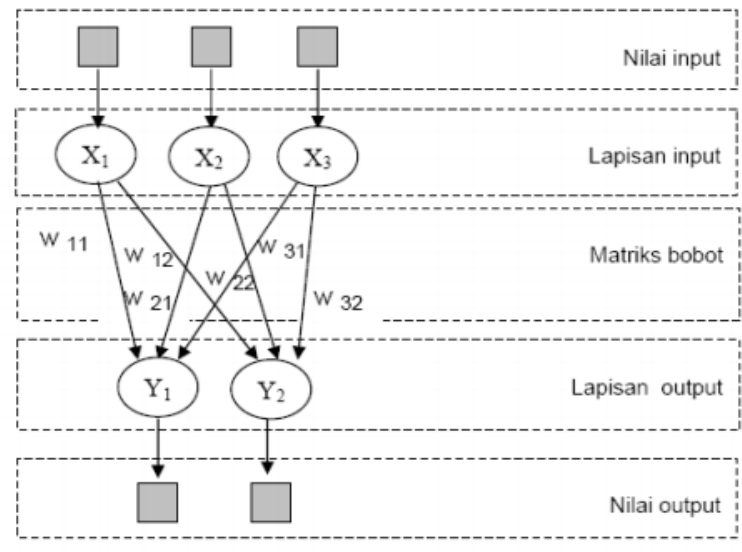

Gbr.1 Jaringan dengan lapisan tunggal

\section{Algoritma Kohonen}

Algoritma Kohonen adalah Merupakan sistem yang dapat menampilkam hasil clustering dan menampilkan visualisasi dengan baik ( Ambarwati, 2014).

Sedangkan menurut (Prabowo, et al 2006) bahwa algoritma kohonen Neural Network merupkan analogi sederhana dari cara kerja otak manusia dalam mengelompokan informasi. Didalam jurnal gadis, et al 2010 dalam jurnalnya yang berjudul penerapan kohonen self organized map dalam kuantisasi vektor bahwa kohonen self organized map merupakan salah satu algoritma yang dapat diterapkan untuk mendapatkana hasil yang maksimal.

Algoritma Kohonen:

1. Inisialisasi bobot: wij

Set parameter-parameter tetangga

Set parameter learning rate

2. Kerjakan selama kondisi berhenti bernilai False a. Untuk setiap vektor input $\mathrm{x}$, kerjakan:

1) Untuk setiap j, hitung:

$$
D(J)=\sum_{i}\left(w_{i j}-x_{i}\right)^{2}
$$

2) Tentukan $J$, sampai $D(J)$ minimum

3) Untuk setiap unit $\mathrm{j}$ dengan spesifikasi tetangga tertentu dan untuk setiap i: $w i j($ baru $)=w i j($ lama $)+\alpha(x i-w i j(l a m a))$

b. Perbaiki learning rate.

c. Kurangi radius ke-tetangga-an pada waktu-waktu tertentu.

d. Tes kondisi berhenti.

Untuk setiap unit $\mathrm{j}$ pada tetangga $\mathrm{J}$ dan semua $\mathrm{i}$ hitung menggunakan rumus :

$\mathrm{Wij}($ new $)=\mathrm{Wij}($ old $)+\alpha[\mathrm{Xi}-\mathrm{Wij}($ old $)$ 


\section{TINJAUAN PUSTAKA}

\section{A. Data Yang Digunakan}

Untuk mendapatkan hasil yang maksimal maka peneliti melakukan pengumpulan beberapa data masukan. Secara ringkas data input perancangan data dengan jaringan syaraf tiruan untuk data pelatihan dan pengujian, digunakan 15 variabel input yaitu:

X1 : Tenggorokan Sakit

X2: Suhu Demam

X3 : Muncul Ruam dalam Tubuh

X4 : Penuruan Berat Badan

X5 : Diare

X6 : Kelelahan

X7 : Nyeri Persendian

$\mathrm{X} 8$ : Nyeri Otot

X9 : Kelenjar Getah Bening membengkak

$\mathrm{X} 10$ : Demam yang berlangsung selama 10 hari

$\mathrm{X} 11$ : Berkeringat dimalam hari

$\mathrm{X} 12$ : Bintik-bintik ungu yang tidak hilang pada kulit

$\mathrm{X} 13$ : Sesak napas

X14 : Infeksi jamur pada mulut, tenggorokan dan Alat kelamin pada Wanita

X15 : Mudah Memar atau berdarah tanpa sebab

\section{B. Flowchart Sistem}

Berikut flowchart sistem yang digunakan untuk program :

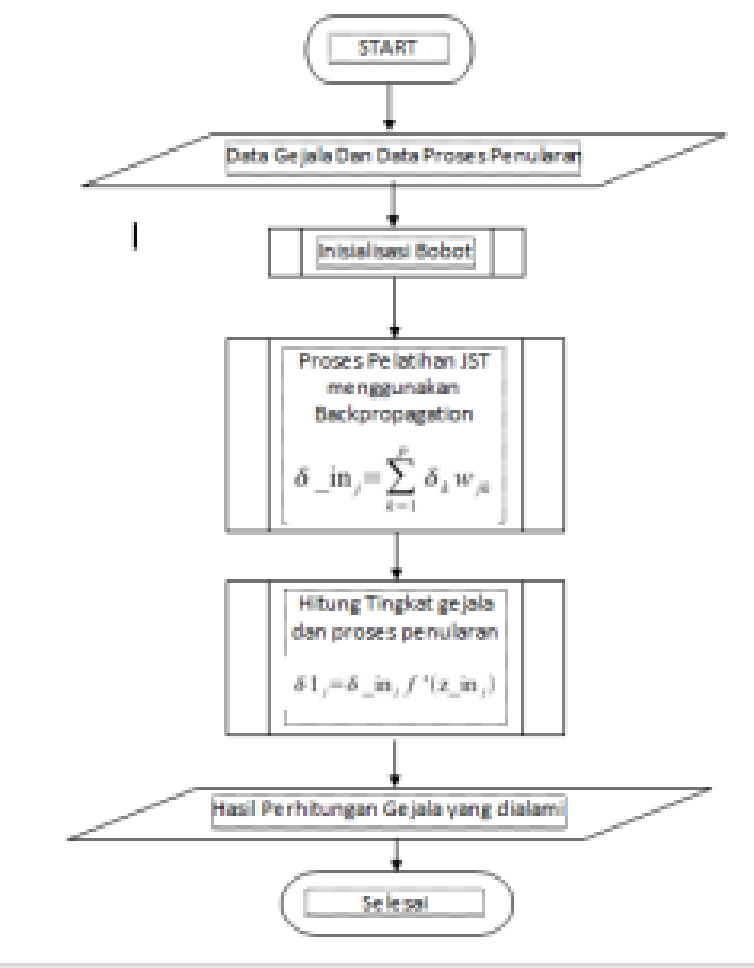

Gbr.2 Flowchart Sistem

\section{HASIL DAN PEMBAHASAN}

\section{A. Pengujian Data}

Dalam tahap ini penulis hanya melakukan tahap pengujian untuk mendapatkan keakuratan nilai output yang mendekati target. Penulis melakukan 3 tahap pengujian untuk mendapatkan hasil yang maksimal dari target output dan mendapatkan nilai error yang kecil untuk mengenal pola penyakit HIV dan AIDS serta MSE (Mean Square Error). Dan juga mendapatkan grapik menuju goal ataupn target yang ditentukan. Pada tahap ini maka akan melakukan akan menghasilkan nilai Output yang terbaik untuk mendekati pola yang diingikan. Pada setiap data yang input akan menghasilkan nilai output yang berbeda sesuai dengan aristektur yang digunakan. Pada tahap ini penulis akan menggunakan arsitektur 15-4-1 untuk mendapatkan nilai output dari target yang ditentukan.

Pada pengujian tahap 1 ini akan melakukan Dapat dilihat pada gambar 3 berikut ini :

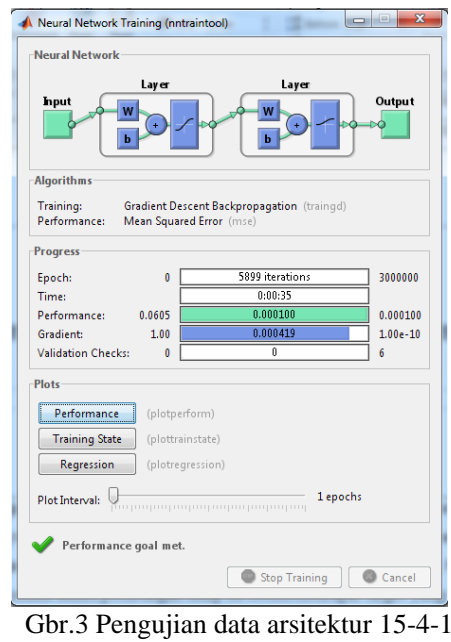

Pada saat pengujian data menggunakan arsitektur 15-4-1 untuk mendapatkan nilai output dari target yang ditentukan maka proses perhitungannya membutukan waktu 35 detik. Untuk melihat bentuk grafik dari arsitektur ini dilihat pada gambar 4 berikut ini :

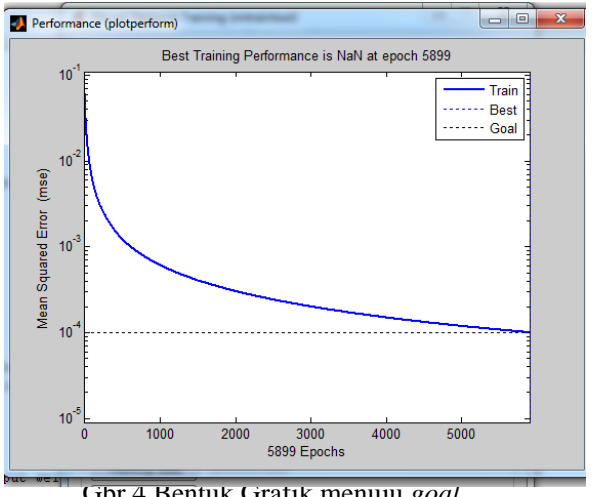

Dari hasil pengujian tahap 1 maka akan mendapatkan error dan output dari target yang ditentukan serta MSE (Mean Square Error ) dan jumlah keakuratan dalam, berapa persen (\%) untuk menuju target yang diinginkan. Berikut dilihat pada tabel I berikut ini : 
TABEL I

HASIL MSE KEAKURATAN

\begin{tabular}{|c|c|c|c|c|c|}
\hline NO & Nama & Target & output & Error & MSE \\
\hline 1 & A & 1 & 0,9958 & 0,0042 & 0,0000176400 \\
\hline 2 & B & 1 & 0,9985 & 0,0015 & 0,0000022500 \\
\hline 3 & C & 1 & 0,991 & 0,009 & 0,0000810000 \\
\hline 4 & E & 1 & 0,9987 & 0,0013 & 0,0000016900 \\
\hline 5 & D & 1 & 0,9961 & 0,0039 & 0,0000152100 \\
\hline 6 & F & 1 & 0,9794 & 0,0206 & 0,0004243600 \\
\hline 7 & G & 1 & 0,9875 & 0,0125 & 0,0001562500 \\
\hline
\end{tabular}

Dengan menggunakan arsitektur ini maka yang mendekati keakuratan nilai output yang terbaik hanya 4. Serta keakuratan dalam persen (\%) hanya mendapat $56 \%$, dengan total error 0, 0530 dan total MSE ( Mean Square Error ) 0, 0006984000 yang mana dalam perhitungan tahap ini belum mencapai target yang ditentukan.

Script yang digunakan untuk mendapatkan nilai output dan error menggunakan matlab :

$[a, P f, A f, e, P e r f]=\operatorname{sim}($ net $, p,[],[], t)$

Nilai bobot yang didapatkan untuk menuju hidden layer, dapat dilihat pada tabel II dibawah ini :

TABEL II

BOBOT MENUJU HIDDEN LAYER

\begin{tabular}{|c|c|c|c|c|}
\hline Variabel & \multicolumn{4}{|c}{ BOBOT MENUJU HIDDEN LAYER } \\
\hline X1 & 65.4893 & 63.2937 & -72.8988 & 63.1450 \\
\hline X2 & 12.5163 & -28.5272 & -19.6722 & 32.544 \\
\hline X3 & 95.1534 & 72.4756 & -66.8805 & 71.8497 \\
\hline X4 & 0 & 0 & 0 & 0 \\
\hline X5 & 95.1296 & -2.2810 & 58.6845 & 54.7034 \\
\hline X6 & -6.2803 & 64.8446 & 57.1067 & 70.1895 \\
\hline X7 & 0 & 0 & 0 & 0 \\
\hline X8 & 0 & 0 & 0 & 0 \\
\hline X9 & 0 & 0 & 0 & 0 \\
\hline X10 & 6.4795 & -14.4793 & 13.6422 & 13.2550 \\
\hline X11 & 0 & 0 & 0 & 0 \\
\hline X12 & 0 & 0 & 0 & 0 \\
\hline X13 & 0 & 0 & 0 & 0 \\
\hline X4 & 37.1921 & 40.2012 & 47.5159 & 16.4628 \\
\hline X5 & 32.3526 & -51.2869 & 40.2681 & -71.5146 \\
\hline
\end{tabular}

Untuk mendapatkan nilai bobot dari menggunakan matlab sebagai berikut :

net.IW $\{1,1\}$

sedangkan untuk mendapatkan nilai bias dapat dilihat pada tabel III sebagai berikut :
TABEL I

NILAI BIAS

\begin{tabular}{|c|c|}
\hline Hidden layer & Nilai \\
\hline 1 & -50.2572 \\
\hline 2 & 60.384 \\
\hline 3 & 75.998 \\
\hline 4 & -12.8791 \\
\hline
\end{tabular}

Tabel diatas merupakan nilai bias dari untuk menuju hidden layer, sedangkan untuk nilai weight dari hidden layer menuju output dpat dilihat pada tabel IV dibawah ini :

TABEL IV

NILAI UNTUK OUTPUT

\begin{tabular}{|c|c|c|c|c|}
\hline Nilai & \multicolumn{4}{|c|}{ Weight } \\
\hline 1 & -0.8640 & -1.7577 & -1.5603 & 12.528 \\
\hline
\end{tabular}

Untuk mendapatkan nilai weight menggunakan matlab : net. $L W\{2,1\}$

\section{B. Pengujian Dengan Algoritma Kohonen}

Pada tahap ini penulis melakukan pengujian cluster menggunakan algoritma kohonen, yang dimana algoritma ini akan mengcluster penyakit dari data yang diinput. Dalam pengujian ini akan menggunakan 100 treshold dan target 1 dari perhitungan epoch sebanyak 10525 yang ada di algoritma backpropagation. Dimana epoch yang didapat diambil dari pengujian tahap 2 dengan 2 hidden layer yang digunakan. Untuk melihat hasil dari algoritma kohonen Dapat dilihat pada gambar 5 berikut ini :

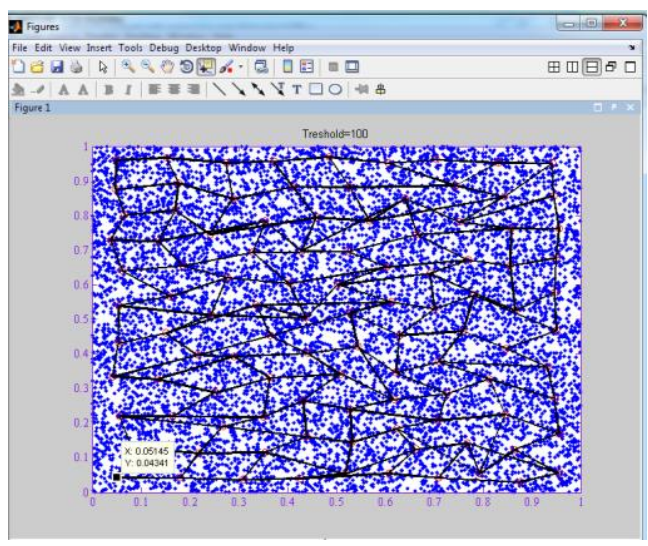

Gbr.5 Hasil Clustering

\section{KESIMPULAN DAN SARA}

A. Kesimpulan

Dari hasil penelitian yang diuraikan diatas penulis mendapatkan kesimpulan sebagai berikut :

1. Dalam algoritma kohonen dan algoritma Backpropagation dapat melakukan pembelajaran untuk mengenal pola penyakit. 
2. Pada jaringan syaraf tiruan Backpropagation dapat mengenal pola penyakit berdasarkan gejala-gejala yang didapat.

3. Dalam pengenalan pola melakukan 3 tahap pengujian menggunakan jaringan syaraf tiruan backpropagation untuk mendapatkan nilai yang maksimum.

\section{B. Saran}

Dalam penelitian ini masih banyak kekurangan maupun kelemahan oleh karena itu ada beberapa saran untuk penelitian selanjutnya :

1. Untuk selanjutnya disarankan untuk menggunakan algoritma yang lain untuk mengenal pola penyakit.

2. Disarankan menggukan data yang lebih banyak untuk mendapatkan nilai yang lebih baik.

\section{REFERENSI}

[1] Ambarwati, \& Edi Winarko (2014) "Pengelompokan Berita Indonesia Berdasarkan Histogram Kata Menggunakan SelfOrganizing Map”, Jurnal IJCCS, Vol.8, No.1, hal 100-110.

[2] Matondang Z. A. (2013) "Jaringan Syaraf Tiruan Dengan Algoritma Backpropagation Untuk Penentuan Kelulusan Sidang Skripsi”, Jurnal Pelita Informatika Budi darma

[3] Nazla Nurmila, "Algoritma Backpropagation Neurak Network Untuk Pengenalan Pola Karakter Huruf Jawa“,Jurnal Masyarakat Informatika, Volume 1 hal 1-10.

[4] Nur Nafi'iyah, (2015), "Algoritma Kohonen Dalam Mengubah Citra Graylevel Menjadi Citra Biner", Jurnal Ilmiah Teknologi Dan Informasia Asia (Jitika), Vol. 9, No.2, hal 49-55.

[6] Prabowo A, (2006) "Perbandingan Antara Metode Kohonen Neural Network dengan Metode Learning Vector Quantization Pada Pengenalan Pola Tandatangan"(jurnal) Jurnal sains \& matematika (JSM), volume 14, nomor 4.

[7] Wuryandari M. D., Afrianto I., (2012) "Perbandingan Metode Jaringan Syaraf Tiruan Backpropagation Dan Learning Vector Quantization Pada Pengenalan Wajah" Jurnal Komputer dan Informatika (KOMPUTA), Edisi I Volume I. 